\title{
Immunity of replicating Mu to self-integration: a novel mechanism employing MuB protein
}

\author{
Jun Ge, Zheng Lou, Rasika M Harshey*
}

\begin{abstract}
We describe a new immunity mechanism that protects actively replicating/transposing Mu from self-integration. We show that this mechanism is distinct from the established cis-immunity mechanism, which operates by removal of MuB protein from DNA adjacent to Mu ends. MuB normally promotes integration into DNA to which it is bound, hence its removal prevents use of this DNA as target. Contrary to what might be expected from a cisimmunity mechanism, strong binding of MuB was observed throughout the Mu genome. We also show that the cis-immunity mechanism is apparently functional outside Mu ends, but that the level of protection offered by this mechanism is insufficient to explain the protection seen inside Mu. Thus, both strong binding of MuB inside and poor immunity outside Mu testify to a mechanism of immunity distinct from cis-immunity, which we call 'Mu genome immunity'. MuB has the potential to coat the Mu genome and prevent auto-integration as previously observed in vitro on synthetic A/T-only DNA, where strong MuB binding occluded the entire bound region from $\mathrm{Mu}$ insertions. The existence of two rival immunity mechanisms within and outside the Mu genome, both employing MuB, suggests that the replicating Mu genome must be segregated into an independent chromosomal domain. We propose a model for how formation of a 'Mu domain' may be aided by specific Mu sequences and nucleoid-associated proteins, promoting polymerization of MuB on the genome to form a barrier against selfintegration.
\end{abstract}

\section{Background}

Transposition is a double-edged sword, allowing elements to populate new sites within their host genomes while potentially exposing their own DNA to self-disruption. Several bacterial transposons including members of the $\operatorname{Tn} 3$ family, $\operatorname{Tn} 7$ and bacteriophage $\mathrm{Mu}$ display transposition immunity [1]. These elements avoid insertion into DNA molecules that already contain a copy of the transposon (a phenomenon called cisimmunity) and it is thought that this form of self-recognition must also provide protection against self-integration. Cis immunity does not provide protection to the whole bacterial genome on which the transposon is resident, but can extend over large distances from the chromosomal site where the transposon is located, or over an entire plasmid harboring the transposon.

In vitro studies with phage $\mathrm{Mu}$ provided the first molecular insights into the cis-immunity phenomenon $[2,3] . \mathrm{Mu}$ transposition requires two $\mathrm{Mu}$ proteins: (1)

\footnotetext{
* Correspondence: rasika@uts.cc.utexas.edu

Section of Molecular Genetics and Microbiology and Institute of Cellular and Molecular Biology, University of Texas at Austin, Austin, TX 78712, USA
}

the MuA transposase, which binds specifically to the ends of $\mathrm{Mu}$ and catalyzes the DNA breakage and joining reactions of transposition, and (2) MuB, an ATP-dependent DNA-binding protein that directs the transpososome complex to integrate into DNA to which $\mathrm{MuB}$ is bound $[4,5]$. MuA-MuB interaction also stimulates the ATPase activity of $\mathrm{MuB}$ and promotes its dissociation from DNA. This latter activity has been demonstrated to be the basis of the observed transposition immunity of mini-Mu plasmids in vitro; that is, $\mathrm{MuB}$ bound to plasmid DNA dissociates upon interaction in cis with $\mathrm{MuA}$ bound to the $\mathrm{Mu}$ ends, resulting in $\mathrm{MuB}$-free DNA, which is a poor target for new insertions $[2,6]$. $\mathrm{MuB}$ also dissociates upon interaction with $\mathrm{MuA}$ in trans, but the oligomeric state of MuA, for example, monomer when bound to ends versus multimer when assembled into an active transpososome, may distinguish interactions at the ends that underlie cis immunity from those that promote target capture and transposition in trans [6]. The mechanism of $\operatorname{Tn} 7$ target immunity is related to that of $\mathrm{Mu}$. Like $\mathrm{Mu}, \mathrm{Tn} 7$ also has an ATPdependent target-recognizing protein, TnsC, which can 
control the activity of the transposase TnsAB via ATP hydrolysis $[7,8]$.

Phage Mu uses transposition to amplify its $37 \mathrm{~kb}$ genome at least 100-fold during the lytic growth cycle. To produce viable progeny, $\mathrm{Mu}$ must avoid transposing into itself, a daunting task given that nearly half the host genome is composed of $\mathrm{Mu}$ sequences by the end of the lytic cycle and that Mu lacks target specificity. Target immunity in vivo has been demonstrated with mini-Mu plasmid substrates $[9,10]$, and is assumed to operate within the $\mathrm{Mu}$ genome as well. Support for a cis-immunity mechanism, which would remove $\mathrm{MuB}$ protein from the vicinity of the $\mathrm{Mu}$ genome in vivo, came from studies using a $10 \mathrm{~kb}$ derivative of $\mathrm{Mu}(\mathrm{Mud})$, which was monitored for transposition into Tn10 elements placed at various distances from the Mud element on the Salmonella typhimurium chromosome [11]. A gradient of insertion immunity was observed in both directions from the Mud insertion point, insertion being unobstructed when the separation between the $\operatorname{Tn} 10$ target and Mud was $25 \mathrm{~kb}$, but undetectable when the separation was $5 \mathrm{~kb}$. Immunity decayed more sharply in a gyrase mutant than in a wild-type strain, leading to a proposal that supercoil diffusion promotes transposition immunity [11]. These experiments monitored insertion immunity outside the $\mathrm{Mu}$ ends and not within the $\mathrm{Mu}$ genome.

A different form of immunity against self-integration is observed with retroviruses such as Moloney leukemia virus (MLV) and HIV, which protect their DNA against intramolecular insertion by using a protein called barrier to auto-integration factor (BAF) [12,13]. BAF, a dimeric protein and a cellular component of viral pre-integration complexes, bridges viral DNA non-specifically and condenses it $[14,15]$. BAF appears to play a dual role, compacting DNA reversibly to prevent auto-integration on the one hand, while promoting intermolecular target capture on the other [16]. MuB has the potential to provide a BAF-like immunity mechanism, as it can polymerize non-specifically on DNA [17]. MuB has a preference for AT-rich DNA [18] and was observed to bind strongly to synthetic A/T-only DNA, where it probably formed a continuous filament [19]. The MuBbound region was refractory to integration. Although $\mathrm{MuB}$ is not expected to bind stably in the interior of the $\mathrm{Mu}$ genome because the $\mathrm{A} / \mathrm{T}$ content of this region is low [20], A/T content is not a reliable predictor of $\mathrm{Mu}$ behavior in vivo. Higher binding of MuB was observed to hot versus cold gene targets, even though the hot genes had an average $\mathrm{A} / \mathrm{T}$ content and cold genes had higher A/T values [19]. MuB binding is expected to be modulated by host proteins in vivo.

In this work we set out to determine if the $\mathrm{Mu}$ genome is indeed immune to self-integration during replicative transposition, and if so, to test whether this is due to the cis-immunity mechanism. Operation of such a mechanism predicts that $\mathrm{MuB}$ would be cleared from the interior of the $\mathrm{Mu}$ genome (that is, bound poorly there), although $\mathrm{MuB}$ might also bind poorly because of high transcription through $\mathrm{Mu}$ or because of the low A/T content of its genome, both of which are expected to disfavor binding [20-22]. We show that the $\mathrm{Mu}$ genome is indeed fairly refractory to self-insertion in vivo, but that contrary to expectation, MuB binds strongly within $\mathrm{Mu}$. Our data show that this immunity is restricted to the $\mathrm{Mu}$ genome and that the cis-immunity mechanism is apparently operative immediately outside the $\mathrm{Mu}$ ends. We call this new mechanism of immunity 'Mu genome immunity'.

\section{Results}

\section{The Mu genome is immune to integration in vivo}

To test if $\mathrm{Mu}$ is immune to self-integration, we monitored $\mathrm{Mu}$ integration within itself by analyzing DNA in $\mathrm{Mu}$ virions as follows. Mu packages its DNA by a head-full mechanism starting at the left or att $\mathrm{L}$ end until approximately $40 \mathrm{~kb}$ of DNA has been packaged [23]. A segment of the inserted Mu copy is therefore expected to be packaged in the genome of the recipient (Figure 1a). Insertions across representative regions within the $\mathrm{Mu}$ genome were analyzed by PCR, employing a common primer hybridizing to the right or att $\mathrm{R}$ end and a second primer within the $\mathrm{Mu}$ region being tested. This method will detect insertions whose $R$ end is oriented towards the $\mathrm{L}$ end of the recipient in which packaging initiates; the $\mathrm{R}$ end of an oppositely oriented insertion would lie beyond the head-full size of $\sim 40$ $\mathrm{kb}$. Although some bias has been reported at the local level $[24,25], \mathrm{Mu}$ insertions in the Eschericia coli genome generally show no orientation bias at the level of $\mathrm{W} / \mathrm{C}$ strands; we believe that this is true of insertions within $\mathrm{Mu}$ as well and that the data are representative of all insertions. This method will report on both inter- and intra-molecular insertions. As controls, we included three known 'hot', 'cold' and 'average' targets of $\mathrm{Mu}$ - yidP, $r f a S$ and $a h p F$, respectively - [19,22], whose DNA would be linked to the $\mathrm{R}$ end in a packaged genome.

Quantitative PCR (qPCR) was performed to analyze the frequency of insertions within seven regions spanning $\mathrm{Mu}$ (Figure $1 \mathrm{~b}$ ). These are plotted as relative insertion frequency (RIF) values, which represent cycle threshold $(\mathrm{Ct})$ differences between the sample and input $\mathrm{Mu}$ DNA control. Lower RIF values mean lower insertion frequency in the target. RIF values of the hot, cold and average $\mathrm{Mu}$ targets were consistent with expectation. Insertions within all seven regions of $\mathrm{Mu}$ had RIF values similar to the cold target $r f a S$. 
A

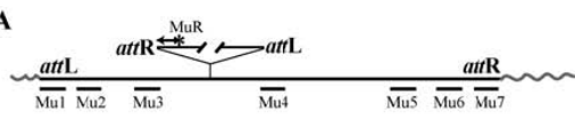

B

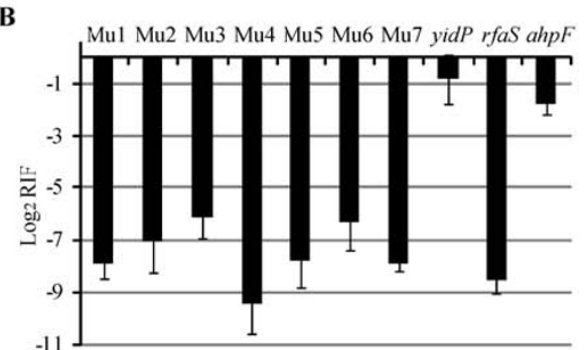

C

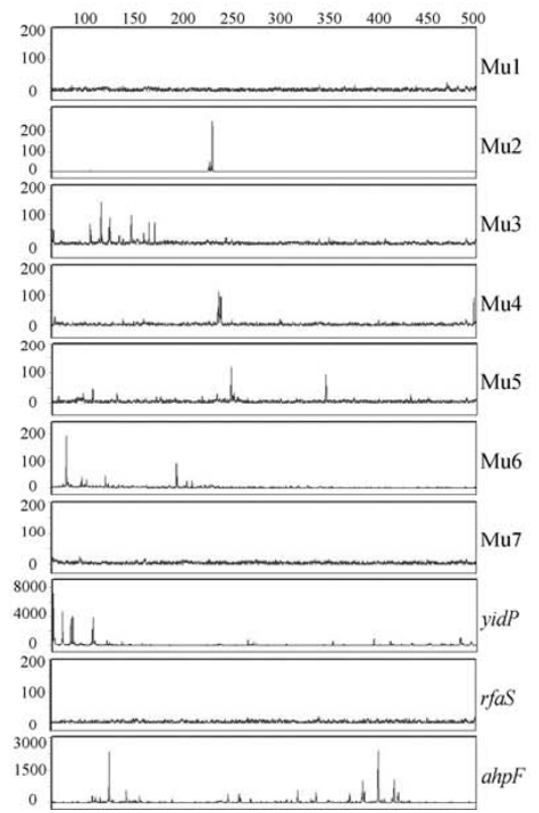

Figure 1 Quantification and profile of $\mathrm{Mu}$ insertions within $\mathrm{Mu}$ in vivo. (a) Experimental strategy. A common MuR primer (labeled* with 6FAM for experiments in (c)), anneals within the right end or attR of Mu. Primers annealing to seven different locations within $\mathrm{Mu}$ (Mu1 to Mu7) were each paired with MuR in PCR reactions to measure (b) the frequency and (c) the site of Mu insertions packaged in phage particles. Wavy lines indicate host DNA linked to Mu ends in packaged phage heads. (b) Real-time PCR reactions were performed using Mu DNA purified from phage prepared after induction of strain SJG3. Ct values are inversely proportional to the amount of nucleic acid of interest in the sample. $\log _{2}$ of the relative insertion frequency (RIF) values were derived from $\mathrm{Ct}$ differences between samples and input Mu DNA control; primer pairs annealing within region 4 served as controls for input DNA. Primers hybridizing to E. coli genes known to be hot (yidP), cold (rfaS) and average (ahpF) Mu insertion targets were also paired with MuR as controls. Primer efficiencies were calculated as described in Methods. The data are an average of three technical repeats. (c) Profile of Mu insertions within the targets monitored in (b). PCR reactions were as in (b), except that MuR was labeled with the fluorescent primer 6FAM. The reactions were subjected to FLA. Numbers on the $X$ axis refer to nucleotides. The intensity of the fluorescent signal reflects the frequency of insertion at a particular site and is represented by arbitrary numbers on the $Y$ axis.
A parallel set of PCR reactions were performed with the MuR primer fluorescently labeled with 6FAM and subjected to Fragment Length Analysis (FLA) to monitor insertion profiles within a 500 bp region in each target (Figure 1c). The heights of the peaks represent the relative frequency of insertion. Insertions into the end regions 1 and 7 of $\mathrm{Mu}$ resembled those in $r f a S$. These regions harbor MuA binding sites, and the transpososome assembled here is expected to prevent access to this DNA. The internal regions 3 to 6 showed a handful of insertions with peak heights of approximately 100 . These values were much lower than those of the majority of insertions in $a h p F$ and $y i d P$, which had peak heights of $>500$, with many insertions showing peak heights up to 4000 .

Data in Figure 1b are derived from the qPCR method, which measures DNA amounts based on the fluorescence signal from SYBR-bound DNA. We assume that $\mathrm{Mu}$ insertions are distributed evenly in the regions tested. Data in Figure 1c are derived from hybridization of a labeled primer and directly reflect the molar amounts of insertions present. The conformity of these two different kinds of measurements increases our confidence in the data. We conclude that the $\mathrm{Mu}$ genome is fairly, but not entirely, immune to integration.

The Mu genome is not immune to integration in vitro Whereas it is known that mini-Mu plasmids are immune to integration and are not used as targets in vitro, the immunity of the whole $\mathrm{Mu}$ genome has not been tested in vitro. We compared the efficiency of use of a mini-Mu plasmid versus the phage $\mathrm{Mu}$ genome as target in transposition reactions employing $\mathrm{MuA}$ and $\mathrm{MuB}$ proteins and the mini-Mu donor plasmid pSP104 (Figure 2a). When incubated with MuA, pSP104 forms a complex called Type I, wherein $\mathrm{Mu}$ ends have undergone single-strand cleavages (lane 1). Inclusion of a target plasmid (pUC19) and $\mathrm{MuB}$ results in efficient integration of pSP104 into pUC19 to give the intermolecular Type II strand transfer complex (lane 2). (The smear of bands around the Type I complex represent intramolecular transposition $[26,27])$. In reactions using pSP104 as donor and the Mu genome as target, the Type I complex was efficiently consumed along with substantial consumption of the linear $\mathrm{Mu}$ genome target, resulting in the appearance of intermolecular Type II strand transfer products of large molecular weight (lane 3). The linear $\mathrm{Mu}$ genome did not itself serve as a donor as shown by absence of any reaction when pUC19 was provided as target (lane 4). A linear donor substrate is not expected to undergo cleavage at $\mathrm{Mu}$ ends, because supercoiling is essential for assembling the transpososome on the paired $\mathrm{Mu}$ ends under these assay conditions [5]. 


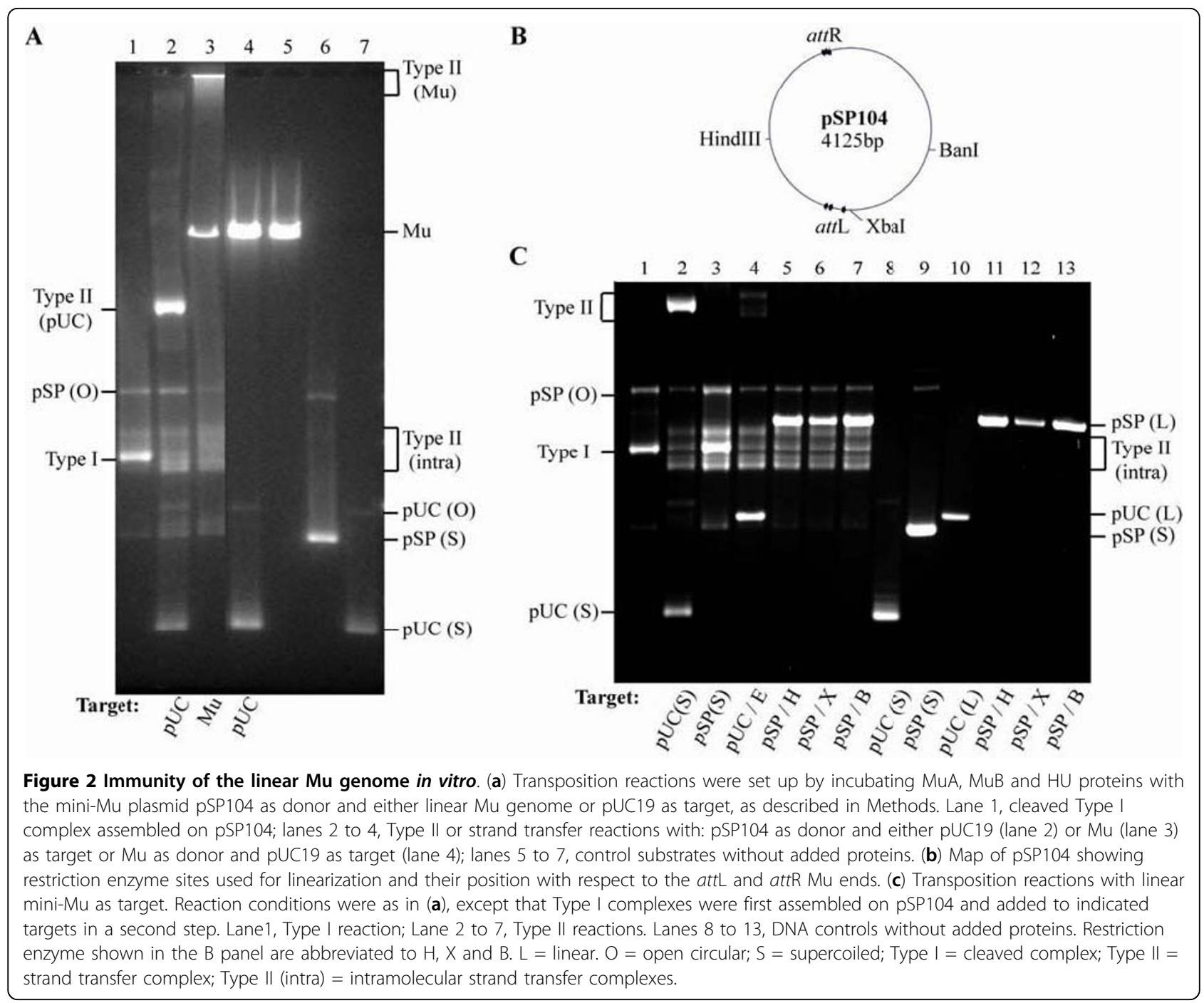

An important difference between the Mu genome substrate in vivo versus that employed in vitro is that $\mathrm{Mu}$ exists as part of the supercoiled E. coli genome in vivo, but is linear when isolated from virions. If lack of immunity of the Mu genome in vitro is due to its linear configuration, a linear mini $\mathrm{Mu}$ plasmid should also not display immunity; that is should serve as target. Three different restriction enzymes sites were used to linearize pSP104 (Figure $2 \mathrm{~b}$ ) to produce different lengths of potential target DNA flanking the Mu ends. Reactions with linearized plasmid pSP104 and linearized control pUC19 are shown in Figure 2c. Type I complex was first assembled on pSP104 (lane 1), and the cleaved complex was subsequently added to various supercoiled and linear targets. Supercoiled pUC19 was used efficiently as target, giving the Type II complex (lane 2), whereas supercoiled pSP104 was simply converted to more Type I and did not serve as target (lane 3). Linear pUC19 was used as a target, but at a lower efficiency (lane 4), whereas linear pSP104 was not used as target, irrespective of the enzyme used for linearization (lanes 5 to 7).

In summary, a linear mini-Mu is immune to integration in vitro, but a linear $\mathrm{Mu}$ genome is not.

Insertions within linear $\mathrm{Mu}$ in vitro are directed to regions away from the ends

Insertions of mini-Mu into linear $\mathrm{Mu}$ obtained in the transposition reaction shown in Figure 2 (lane 3), were analyzed with the same primer pairs used to analyze insertions into the $\mathrm{Mu}$ genome in vivo (Figure 1c). The results are shown in Figure 3. Insertions were absent only at the MuA binding sites near the $\mathrm{Mu}$ ends (region 1 and 7). The end-proximal regions 2 and 6 had fewer insertions compared with the central regions 3 to 5 . This pattern of insertions away from the $\mathrm{Mu}$ ends is consistent with the cis-immunity mechanism clearing $\mathrm{MuB}$ near the vicinity of MuA-bound ends. 


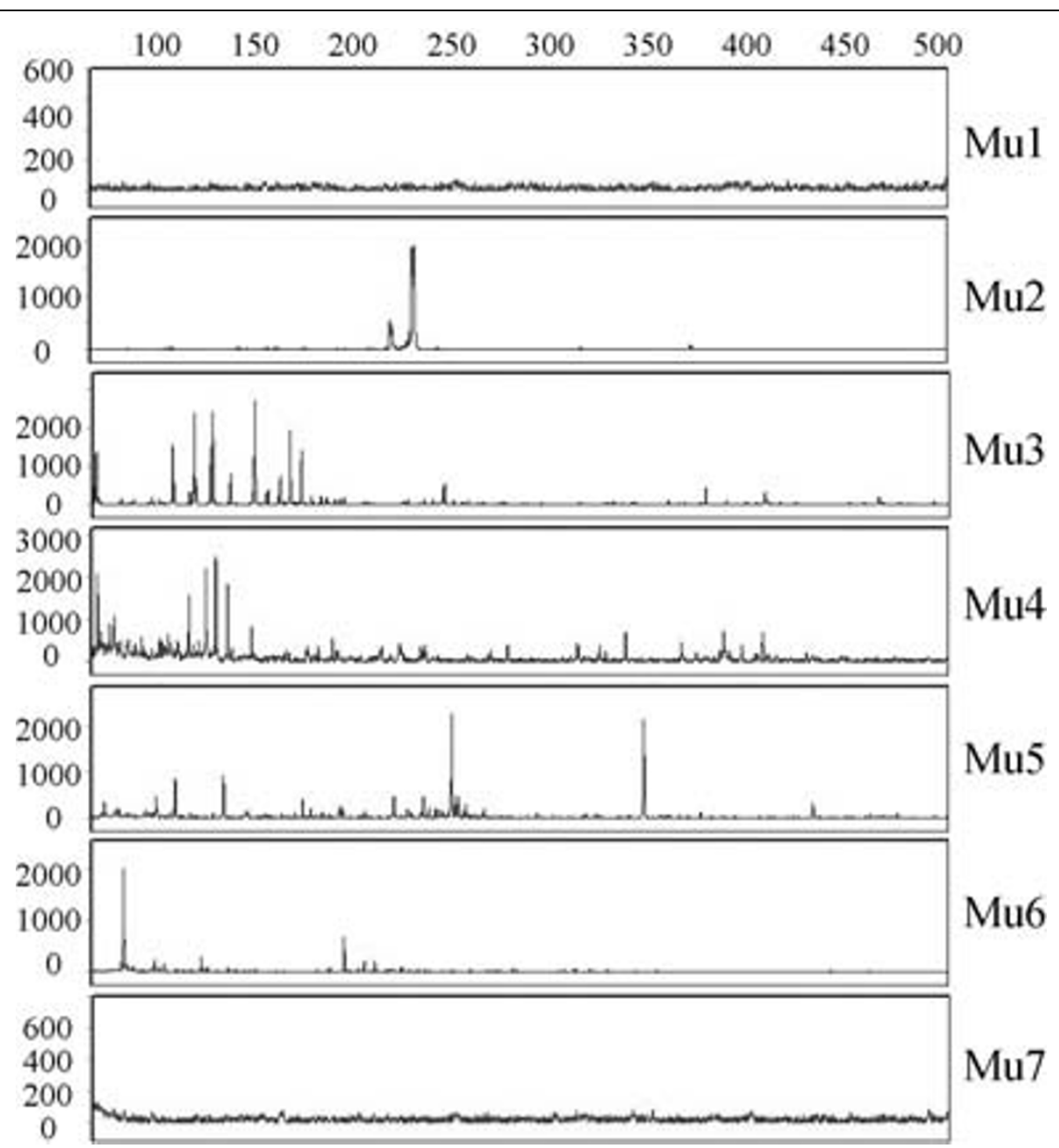

Figure 3 Profile of $\mathbf{M u}$ insertions within the Mu genome in vitro. Reactions were as described in Figure 1c, except that the template for PCR was the in vitro Type II reaction shown in Figure 2, lane 3.

\section{MuB binds throughout the Mu genome in vivo}

From the results shown in Figures 1 to 3, it is clear that the $\mathrm{Mu}$ genome is immune in vivo, but the cis-immunity mechanism is not sufficient to explain this immunity because it does not protect the internal regions of $\mathrm{Mu}$ in vitro. An indicator of an operative cis-immunity mechanism in vivo would be absence of MuB binding within the $\mathrm{Mu}$ genome. In chromatin immune precipitation (ChIP) experiments using MuB antibodies, the PCR signal was not sufficiently strong, so we engineered a cmyc epitope tag at the $\mathrm{N}$-terminus of $\mathrm{MuB}$ on the prophage genome (strain SJG3). MuB is essential for $\mathrm{Mu}$ replication. $\mathrm{c}-\mathrm{myc}-\mathrm{MuB}$ supports normal $\mathrm{Mu}$ replication as judged by normal lysis profiles and phage titers obtained after induction of prophages carrying normal or c-myc-MuB [see Additional file 1, comparing MP1999 to SJG3]. In addition, $\mathrm{Mu}$ insertion profiles within the hot $E$. coli target yidP were similar in strains with either wild-type MuB [19] or c-myc-MuB (compare yidP data from Figure 1 in this study to Figure 3 in reference [19]). Thus, c-myc-MuB is functionally indistinguishable from wild-type MuB. Other tags (His and GFP) at the $\mathrm{N}$-terminus of $\mathrm{MuB}$ have been shown to retain all $\mathrm{MuB}$ functions tested in vitro, including cis immunity $[6,18]$.

$\mathrm{Mu}$ replication was induced in SJG3 by inactivating the temperature-sensitive $\mathrm{Mu}$ repressor at $42^{\circ} \mathrm{C}$. Western blots showed MuB levels increasing continuously after induction of $\mathrm{Mu}$ replication [see Additional file 1]. Cells were harvested at 40 minutes after induction to ensure both an actively replicating $\mathrm{Mu}$ population and adequate $\mathrm{MuB}$ levels. The average $\mathrm{Mu}$ copy number was calculated to be 18 at this time point (see Methods). ChIP samples prepared using c-myc antibody were probed for DNA spanning the seven regions within $\mathrm{Mu}$ (Figure 1) by regular PCR reactions using primer pairs 
within these regions. Mock controls without antibody were used to assess the contribution of non-specific binding. MuB was observed to bind strongly to all seven regions examined (Figure 4). As a control, we also conducted ChIP experiments with anti-MuA antibody in cultures harvested in parallel. MuA binds to specific sites at the $\mathrm{L}$ and $\mathrm{R}$ ends, but is also known to have non-specific DNA-binding activity [5,28]. In reaction conditions equivalent those in the MuB ChIP samples, MuA binding was detected only at the ends and not to internal regions. Because we know that site-specific binding of $\mathrm{MuA}$ to $\mathrm{Mu}$ ends is strong, especially in the context of an assembled transpososome, we interpret the equivalent $\mathrm{MuB}$ signal across all regions of the $\mathrm{Mu}$ genome to represent strong binding. This result is contrary to that expected of the cis-immunity mechanism [2].

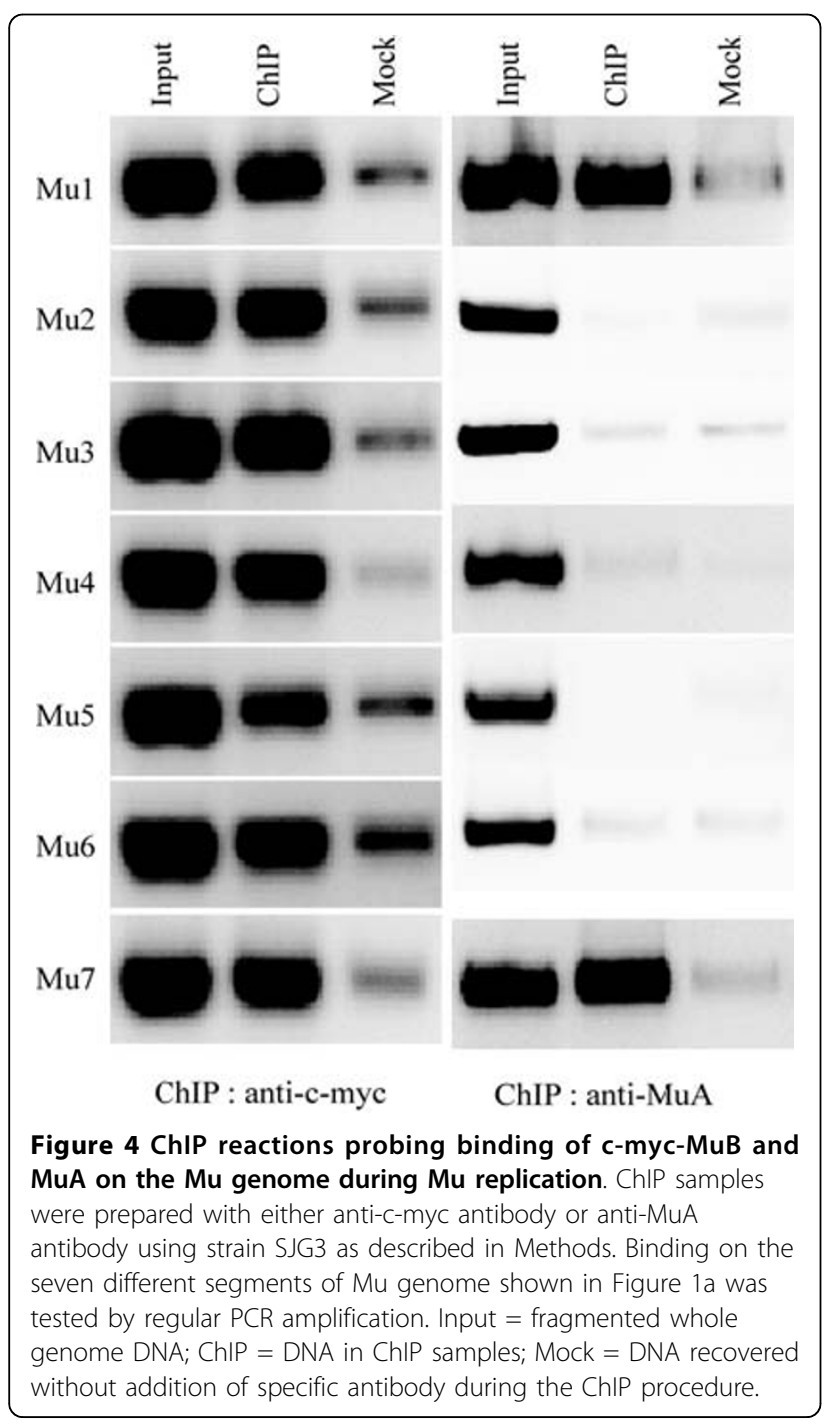

Strong MuB binding is confined to the interior of the $\mathrm{Mu}$ genome

Real-time PCR was used to compare MuB binding across $\mathrm{Mu}$ and to chromosomal DNA flanking the original $\mathrm{Mu}$ insertion in the ChIP samples (Figure 5a). Control hot (yidP) and cold ( $r f a S) \mathrm{Mu}$ targets tested for MuB binding in an earlier study were also used [19], along with average target $a h p F$ (Figure 1). In this earlier study conducted with anti-MuB antibody, the hot target yidP bound $\mathrm{MuB}$ more strongly than did the cold target rfaS. Similar results were seen in this study with anti-cmyc antibody (black bars, SJG3). Within the Mu genome, MuB binding was uniformly high throughout, even though the genome is as cold a target as rfaS (Figure $1 b)$. These values, when corrected for Mu copy number, could be an underestimate if MuB binds only to a subset of $\mathrm{Mu}$ genomes that have finished replication.

To determine how the binding pattern of $\mathrm{MuB}$ within the $\mathrm{Mu}$ genome compares with that in its chromosomal vicinity, the ChIP samples were amplified using primer pairs annealing to known genes flanking the original $\mathrm{Mu}$ insertion. DNA on both sides of the insertion at $\sim 300$ bp, $1 \mathrm{~kb}, 5 \mathrm{~kb}, 10 \mathrm{~kb}$ and $25 \mathrm{~kb}$ from the ends was monitored (L/R 0 to 25, respectively; black bars, SJG3). Binding at L0 to L10 was lower than at L25, and binding at $\mathrm{R} 0$ to $\mathrm{R} 1$ was lower than at R5 to R25.

In summary, strikingly different patterns of MuB binding were seen inside and immediately outside the $\mathrm{Mu}$ genome. Outside the $\mathrm{Mu}$ ends, increased binding away from the ends could be discerned, consistent with a cisimmunity mechanism. Inside $\mathrm{Mu}$, the uniformly high $\mathrm{MuB}$ binding suggests a different mechanism, which operates in the presence of MuB binding.

\section{Chromosome-organizing proteins Fis and H-NS affect}

\section{MuB binding}

The clear distinction in MuB binding patterns between $\mathrm{Mu}$ and non-Mu sequences suggests that there exists a physical boundary between these regions. We therefore considered whether nucleoid-organizing host proteins could be involved in creating a separate 'Mu domain', which promotes MuB binding. The rationale for this came from the longstanding observation that mutations in $\mathrm{H}-\mathrm{NS}$ or Fis, proteins that participate in compacting the E. coli nucleoid [29], de-repress a Mu prophage, indicating their likely presence on the $\mathrm{Mu}$ genome [30-32]. We therefore generated $\Delta$ fis and $\Delta h n s$ mutations in the SJG3 strain, and monitored MuB binding to the $\mathrm{Mu}$ and flanking regions as before. A $\Delta$ fis $\Delta$ hns double mutant was not viable in this background.

Outside the $\mathrm{Mu}$ ends, MuB binding increased significantly at a majority of sites in the fis mutant (Figure 5). The hns mutation had a similar effect only at R25, the overall tendency in this mutant being to decrease $\mathrm{MuB}$ binding at most sites. Fis, $\mathrm{H}-\mathrm{NS}$ and $\mathrm{MuB}$ all prefer $\mathrm{A} /$ 


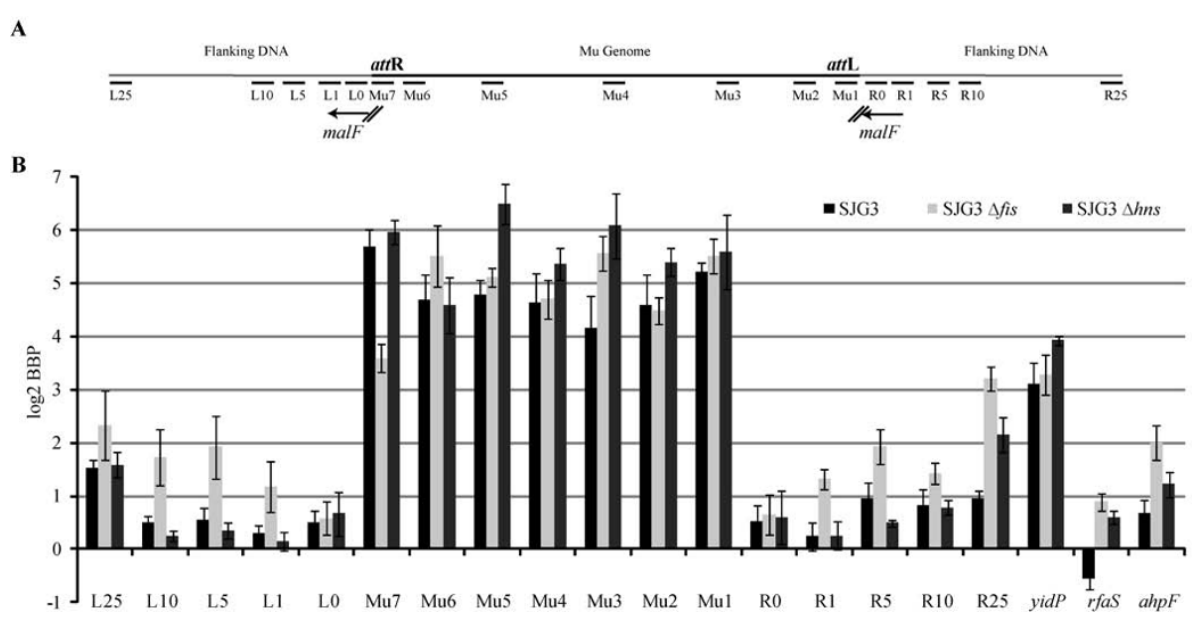

Figure 5 qPCR of DNA isolated by ChIP using anti-c-myc-MuB antibody after induction of Mu replication. (a) Location of DNA segments within and outside the Mu prophage. The Mu insertion is in malF, whose direction of transcription on the E. coli genome is indicated by arrows. The $L 0$ region spans 45 to $328 \mathrm{bp}$ from the beginning of attR, whereas the R0 region spans 89 to $343 \mathrm{bp}$ from the beginning of attL. L1 to L25 and R1 to R25 indicate approximate distance in $\mathrm{kb}$ from the Mu ends. Mu1 to Mu7 amplify the following regions in bp, the numbering starting at 1 on the attL. Mu1: 1 to 350; Mu2: 2,650 to 3,021; Mu3: 9,915 to 10,245; Mu4: 17,641 to 17,983; Mu5: 26,419 to 26,790; Mu6: 34,223 to 34,660; Mu7: 36,421 to 36,717 . See Additional file 3 for primer sequences. (b) MuB binding to regions indicated in A in three Mu lysogen strains: SJG3, SJG3 $\triangle$ fis and SJG3 $\Delta$ hns. Real-time PCR reactions of ChIP samples and Mu copy number estimates were performed as described in Methods. $\mathrm{MuB}$ binding to hot (yidP), cold (rfaS) and average (ahpF) Mu insertion target genes in E. coli was monitored in parallel (see Figure 1). The log 2 BBP values are the Ct difference between ChIP and mock samples for each segment. The data are an average of nine experiments: three independent biological repeats, each with three independent technical repeats. BBP $=$ MuB binding preference.

T-rich DNA and probably compete for similar binding sites. Because Fis is the most abundant nucleoid-associated protein in the cell [33], the increase in MuB binding in the fis mutant could be due to availability of sites previously occupied by Fis. Despite the altered MuB binding patterns in these two mutants, the gradient of increased MuB binding away from the ends was maintained. Such a gradient was strikingly absent inside the $\mathrm{Mu}$ ends, although binding did increase at some locations, primarily in the hns mutant. The cold site $r f a S$ showed increased MuB binding in both mutants, whereas the average site $a h p F$ showed increased binding only in the fis mutant and the hot site yidP increased only in the hns mutant.

In summary, the absence of Fis or $\mathrm{H}-\mathrm{NS}$ changes $\mathrm{MuB}$ binding profiles on DNA. Despite the changed profiles, the gradient of increasing $\mathrm{MuB}$ binding away from the ends is maintained outside $\mathrm{Mu}$, whereas uniform binding is maintained inside $\mathrm{Mu}$.

\section{The Mu genome is far more immune than its flanking} DNA

To test whether the change in MuB binding would change $\mathrm{Mu}$ insertion profiles, $\mathrm{QPCR}$ reactions were conducted for all the $\mathrm{Mu}$ segments and control targets in the fis and hns mutants, as well as for segments L0 to L25, where increased MuB binding was observed in the fis mutant compared with the wild type. Within $\mathrm{Mu}$, a small increase in $\mathrm{Mu}$ insertions was observed only in the central region 4 in both fis and hns mutants (Figure $6 a)$, although MuB binding did not alter substantially in this region (Figure $5 \mathrm{~b}$ ). FLA analysis showed that insertion at a specific site around $240 \mathrm{bp}$ in this region showed a moderate increase in both mutants (Figure $6 b)$. Thus, protection of the Mu genome is largely maintained in these mutants. Interestingly, despite increased $\mathrm{MuB}$ binding, the cold site $r f a S$ became slightly colder in both mutants (Figure 6a and Figure 5b), but the hot site yidP became slightly hotter in the hns mutant. Taken together, these data show that MuB binding makes some regions cold and other regions hot. Therefore, some other cellular feature must modulate $\mathrm{MuB}$ activity to generate the opposing $\mathrm{Mu}$ insertion outcomes.

Outside $\mathrm{Mu}$, in segments $\mathrm{L} 1$ to $\mathrm{L} 25$, a gradient of $\mathrm{Mu}$ insertions was observed in the wild-type SJG3 strain, being lowest at L1 and highest at L25, consistent with the cis-immunity mechanism (Figure 6c). Despite the increased $\mathrm{MuB}$ binding to this region in the absence of Fis (Figure 5), the $\mathrm{Mu}$ insertion frequency did not change significantly in the fis mutant compared with the wild type. The signal at L0 is high because the original insertion in malF is expected to be packaged in around $4 \%$ of phage particles [34].

When insertion patterns inside and outside $\mathrm{Mu}$ are compared, a difference of at least an order of magnitude is observed, the inside being more refractory (compare 


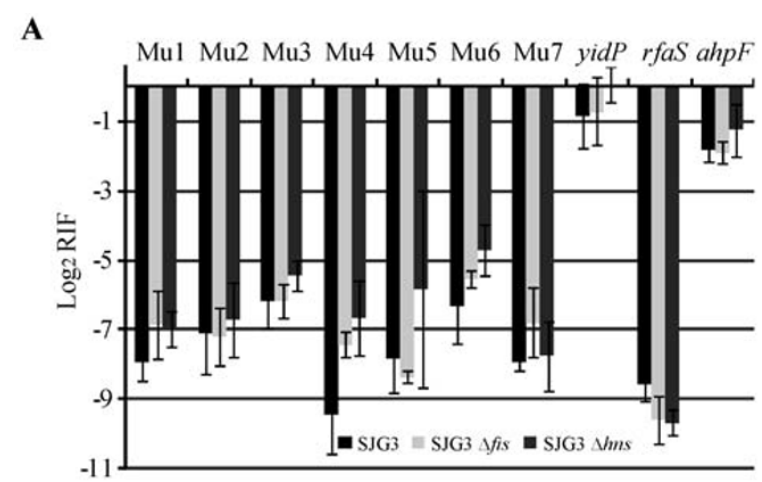

B

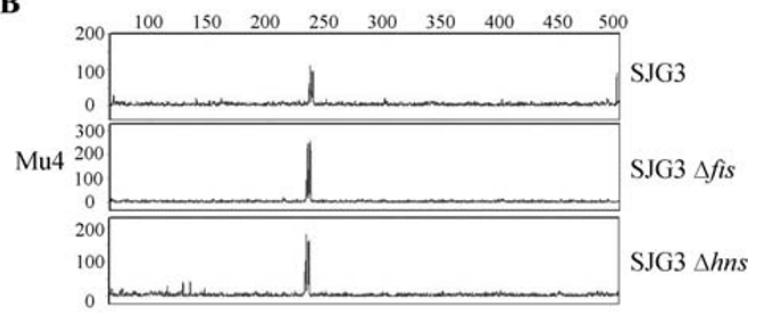

C

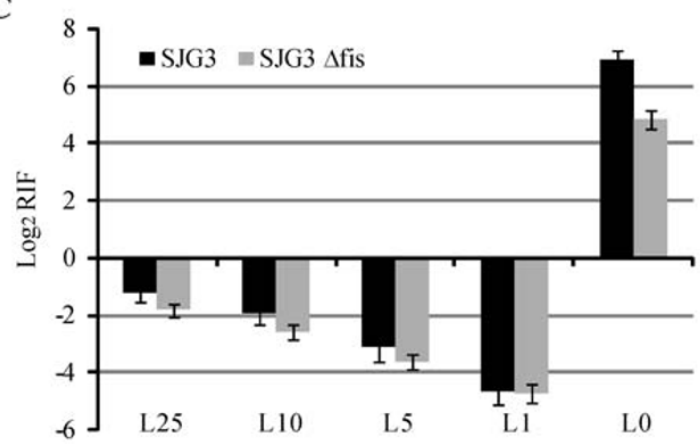

Figure $6 \mathrm{Mu}$ insertions within $\mathrm{Mu}$ and flanking DNA in fis and hns mutants.(a) Data for SJG3 are from Figure 1b. All other descriptions as in Figure 1b. (b) FLA analysis of reactions for the Mu4 region. Other descriptions as in Figure 1c. (b) As in (a), except insertions were monitored in L0 to L25 regions in the indicated strains.

Figure $6 \mathrm{a}$ to $6 \mathrm{c}$ ). For example, in regions close to the $\mathrm{Mu}$ end, there are 15 times more insertions outside at L1 $(1 \mathrm{~kb})$ than at an equivalent distance inside at Mu1-2 $(0-3 \mathrm{~kb})$. A similar difference is seen if one compares L10 (10 kb) outside to Mu3 (10 kb) inside. At L25 outside, the difference in insertion frequency compared with the center of $\mathrm{Mu}(\mathrm{Mu} 4: \sim 18 \mathrm{~kb})$ approaches 100fold. Thus, assuming that the cis immunity mechanism is operative outside, it clearly does not provide the level of protection seen inside.

In summary, both $\mathrm{MuB}$ binding patterns and $\mathrm{Mu}$ insertion frequencies show that different immunity mechanisms must operate within and outside $\mathrm{Mu}$.

\section{Discussion}

This study has revealed a new immunity mechanism we call $\mathrm{Mu}$ genome immunity, which protects replicating $\mathrm{Mu}$ from self-integration. This mechanism is distinct from cis immunity, which appears to be functional immediately outside Mu. Sharply different patterns of $\mathrm{MuB}$ binding and insertion within and outside $\mathrm{Mu}$ on the $E$. coli chromosome indicate the existence of a mechanism for discriminating between the two regions. We propose that $\mathrm{Mu}$ genome immunity is enabled by segregating $\mathrm{Mu}$ into a separate chromosomal domain.

\section{Cis immunity versus $\mathrm{Mu}$ genome immunity}

MuB has been known thus far to promote, not prevent, $\mathrm{Mu}$ integration on natural DNA substrates. MuB is essential both for intermolecular transposition and for cis immunity in vitro $[2,3]$. It seems that cis immunity also operates outside the $\mathrm{Mu}$ ends in vivo as inferred from the observed gradient of increasing $\mathrm{Mu}$ insertions in both directions from a Mud insertion on the S. typhimurium chromosome [11], and from the results of this study on the $E$. coli chromosome where higher $\mathrm{MuB}$ binding was observed away from the ends (Figure $5 b$ ), along with an increasing gradient of $\mathrm{Mu}$ insertions (Figure 6c).

In contrast to the pattern of MuB binding outside $\mathrm{Mu}$ ends, strong and uniform binding was observed inside $\mathrm{Mu}$ along with uniform protection from insertion (Figures 1 and 4). Whereas MuB might be expected to bind strongly to the end regions 1 and 7 because it is associated with transpososomes assembled on the ends $[35,36], \mathrm{MuB}$ is not expected to be bound inside if the cis-immunity mechanism were operative here [2].

An interesting property of $\mathrm{MuB}$ is its proclivity to polymerize cooperatively and non-specifically on DNA, with a tendency to form larger polymers on A/T-rich DNA $[17,37]$. On natural DNA, which can range from $40 \%$ to $70 \% \mathrm{~A} / \mathrm{T}$, analysis of $\mathrm{MuB}$ binding and $\mathrm{Mu}$ insertion patterns is consistent with a fairly interspersed pattern of $\mathrm{MuB}$ binding, with insertions being directed to adjacent DNA sites free of MuB [19]. The pattern of $\mathrm{Mu}$ insertion within such DNA is unperturbed over a wide range of $\mathrm{MuB}$ concentrations. On the other hand, $\mathrm{MuB}$ binds strongly to synthetic DNA that is $100 \% \mathrm{~A} / \mathrm{T}$, protecting the bound DNA even at low MuB concentrations [19]. MuB binding could therefore theoretically protect the $\mathrm{Mu}$ genome against $\mathrm{Mu}$ insertion if it were to form a tightly-bound filament on it. The barrier to integration presented by a continuous $\mathrm{MuB}$ filament offers an alternative and antithetical (to the cis-immunity) mechanism to explain $\mathrm{Mu}$ genome immunity. However, the $\mathrm{Mu}$ genome is devoid of features known to promote stable $\mathrm{MuB}$ binding in vitro. Only the $\mathrm{Mu}$ 
ends are A/T-rich, and there is a gradient of high to low $\mathrm{A} / \mathrm{T}$ from the ends to the center of $\mathrm{Mu}$ (Additional file 2 ). Thus, some feature other than $A / T$ content is responsible for strong $\mathrm{MuB}$ binding here.

\section{Nucleoid-associated proteins and Mu transposition}

The bacterial genome is folded into a compact structure called the nucleoid. Many architectural proteins associate with the nucleoid and contribute to the folding and compaction by bridging, bending or wrapping DNA, which is organized into many supercoiled domains $[38,39]$. There are estimated to be 50 to 400 supercoiled DNA loops, which are on average about $10 \mathrm{~kb}$ in size [39-41]. These DNA loops are discrete chromosomal territories that are topologically independent and dynamic, and are maintained by the activity of the nucleoid-associated proteins (NAPs), many of which bind to A/T-rich DNA. AT-rich sequences are also found at the ends and center of the Mu genome (Additional file 2), suggesting that $\mathrm{Mu}$ may form an independent chromosomal domain, aided by the binding of NAPs.

Of the dozen or so NAPs found in E. coli [42], most research has focused on the abundant proteins $\mathrm{H}-\mathrm{NS}$, Fis, HU and integration host factor (IHF). In contrast to eukaryotes, in which protein-mediated compaction is attributed exclusively to histones, none of these proteins is solely responsible for DNA compaction. Bacterial cells deficient in one of the NAPs usually have subtle phenotypes, which indicate that (some of) the roles of one NAP can be fulfilled by another. Double mutations of HU/Fis or HU/IHF often have more severe effects. In this study, we tested the contribution of $\mathrm{H}-\mathrm{NS}$ and Fis to $\mathrm{MuB}$ binding and $\mathrm{Mu}$ genome immunity because these proteins have been shown to play a role in the stable maintenance of a Mu prophage in E. coli [30-32]. Fis is the most abundant protein in E. coli [33]. H-NS is a transcriptional repressor for many genes and has been shown to bind and silence 'foreign' DNA in Salmonella [43]. It can bridge two DNA helices, a property thought to aid in compacting the nucleoid, and has been demonstrated to stabilize the $\operatorname{Tn} 10$ transpososome by interacting with both DNA and the transposase [44].

In the absence of either $\mathrm{H}$-NS or Fis, MuB binding was altered on the DNA regions outside the Mu ends, being more pronounced in the fis mutant (Figure 5). A general increase in $\mathrm{MuB}$ binding was also observed inside $\mathrm{Mu}$ in both mutants. However, both regions maintained the same level of insertion immunity as the wild-type strain (Figure 6). Representative hot and cold genes located away from $\mathrm{Mu}$ showed opposite behaviors in response to MuB changes. With increased MuB binding, the cold gene rfaS got colder whereas the hot gene yidP got hotter. These results suggest that MuB binding patterns are influenced by host NAPs, but that these patterns are not the sole determinants of $\mathrm{Mu}$ insertion frequencies. Some other cellular feature overrides the known properties of $\mathrm{MuB}$ and alters its activity.

\section{A model for Mu genome immunity}

$\mathrm{Mu}$ ends define a boundary separating two modes of $\mathrm{MuB}$ binding and immunity. We propose that Mu genome immunity arises from a special structure that $\mathrm{Mu}$ adopts, aided by both specific Mu sequences and by general cellular NAPs (Figure 7). In the center of the genome is the strong gyrase-binding site (SGS), which is essential for $\mathrm{Mu}$ replication in vivo and is believed to function by influencing efficient synapsis of the $\mathrm{Mu}$ ends [45-48]. The SGS is thought to act by localizing the $37 \mathrm{~kb} \mathrm{Mu}$ prophage DNA into a single loop of plectonemically supercoiled DNA upon binding of DNA gyrase to the site. The SGS, predicted to reside at the turnaround of the loop, would constrain the two $\mathrm{Mu}$ ends to the same supercoiled domain to facilitate synapsis. We propose that an SGS-generated Mu loop, sealed off at the $\mathrm{Mu}$ ends by either the transpososome or NAPs, serves as a scaffold for nucleating MuB filaments in the $\mathrm{Mu}$ interior, providing a barrier to $\mathrm{Mu}$ integration. We draw parallels between $\mathrm{Mu}$ genome immunity and the immunity conferred by the BAF protein in HIV and MLV, which, along with other cellular proteins, compact the retroviral genomes and prevent auto-integration $[49,50]$. Whereas MuB has not been demonstrated to bridge two DNA helices like other DNA compacting proteins, DNA binding has been observed in both domains of this bi-domain protein [51,52]. Single molecule experiments with $\mathrm{MuB}$ have been carried out with DNA held in an extended conformation in a flow cell, a condition not expected in natural chromosomal DNA [53]. However, MuAand MuB-dependent DNA looping has been observed when the flow of buffer was relaxed in this device [6]. DNA looping was also observed in BAF and Fis in similar experiments, and has been proposed to be the mechanism responsible for DNA condensation by both proteins [50,54].

Our results open a new frontier for understanding $\mathrm{Mu}$ genome immunity, and pose many new questions. For example, what is the timing of establishment of this immunity? How does immunity to integration still allow other processes such as transcription and replication to go on, if indeed they do? Is it possible that strong $\mathrm{Mu}$ transcription initially disfavors integration, but that replication through the genome marks it for genome immunity?

\section{What is cis immunity good for?}

Both in vivo and in vitro data presented in the study show that the cis-immunity mechanism is an ineffective strategy for protecting the interior of $\mathrm{Mu}$. In vivo, the region between 1 and $25 \mathrm{~kb}$ outside a $\mathrm{Mu}$ end had 


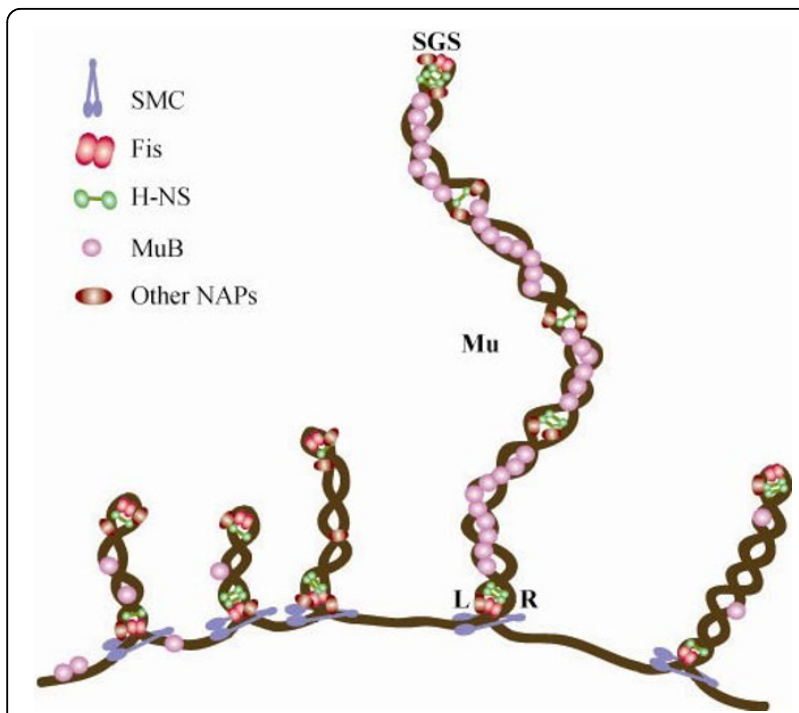

Figure $7 \mathrm{~A}$ model for Mu genome immunity. The model proposes that segregation of $\mathrm{Mu}$ into a separate domain on the $E$. coli chromosome is aided by the centrally located SGS, which initiates loop formation, and is sealed by either the Mu transpososome assembled on the ends or NAPs. Several NAPS are shown stabilizing this structure, hypothesized to promote formation of MuB filaments, which provide a barrier against selfintegration. Fis and H-NS may be expected to reside at the SGS and $\mathrm{Mu}$ ends because these proteins prefer $\mathrm{A} / \mathrm{T}$ rich regions (see Additional file 2). SMCs have been proposed to be involved in the creation of large topological loops by bridging two DNAs at the base of the stem of such loops [29,39].

10 to 100 fold more insertions than the region within a similar distance inside (Figure 6). In vitro, the linear $\mathrm{Mu}$ genome was not protected from mini-Mu insertions, particularly in internal regions (Figures 2 and 3 ). If cis immunity is neither effective nor operative inside the $\mathrm{Mu}$ genome, its role seems to be limited to discouraging $\mathrm{Mu}$ insertions immediately next to the ends. What is the importance of such a mechanism in the life of $\mathrm{Mu}$ ? One possibility is that, because $\mathrm{Mu}$ packages flanking DNA, avoiding insertions in this DNA avoids packaging orphan L or R ends, which might interfere with assembly of the transpososome on the correct $\mathrm{Mu}$ ends in a new host. However, the $\mathrm{Mu}$ synapse is assembled in a highly ordered manner on three sites ( $\mathrm{Mu}$ ends and an internal enhancer site) [55,56], and is topologically unique [57-59], a design that should inherently exclude incorrectly oriented 'extra' ends [60]. A second possibility is that discouraging use of nearby targets increases sampling of other regions of the chromosome, because some insertion locations are difficult to transpose out of [61]. A third possibility is that cis immunity is simply a byproduct of biochemical properties of $\mathrm{MuB}$ and $\mathrm{MuA}$ and has no real relevance in vivo.

\section{Conclusions}

A new immunity mechanism we call $\mathrm{Mu}$ genome immunity protects actively replicating/transposing $\mathrm{Mu}$ from self-integration. This mechanism is associated with strong $\mathrm{MuB}$ binding within the $\mathrm{Mu}$ genome. The cisimmunity mechanism, which requires removal of $\mathrm{MuB}$ from DNA adjacent to $\mathrm{Mu}$ ends, is apparently functional immediately outside $\mathrm{Mu}$, but the level of protection offered by this mechanism is insufficient to explain the protection seen inside. The sharply different patterns of $\mathrm{MuB}$ binding inside and outside Mu suggest that the $\mathrm{Mu}$ genome is segregated into an independent chromosomal domain. We propose a model for how formation of an independent 'Mu domain' might nucleate polymerization of $\mathrm{MuB}$ on the genome, forming a barrier against self-integration. We speculate that $\mathrm{Mu}$ genome immunity might be functionally similar to the immunity conferred by eukaryotic cellular BAF protein to HIV or MLV retroviral genomes. Our results also reveal that whereas MuB binding is sensitive to the presence of host nucleoid-associated proteins, $\mathrm{MuB}$ binding patterns are not the sole determinants of $\mathrm{Mu}$ insertion frequencies; some other cellular feature overrides the known properties of $\mathrm{MuB}$ and alters its activity.

\section{Methods}

\section{Bacterial strains, DNA and proteins}

E. coli $\mathrm{Mu}$ lysogen strain MP1999 [recB, recC, sbcB, malF::Mucts62] [46] was used to construct strain SJG3 (MP1999 MuB:::9c-mycB) and its two derivative mutants SJG3 $\Delta$ fis and SJG3 $\Delta$ hns. All deletions/substitutions were generated by the $\lambda$ Red recombination system using amplification primers listed in Additional file 3 [62]. In SJG3, the $M u B$ gene in the prophage is substituted with $9 c-m y c B$, introducing an additional $381 \mathrm{bp}$ at this location. This replacement was by a two-step procedure, first introducing a cat-sacB cassette into $\mathrm{Mu} B$ in MP1999, selecting for Cam resistance, and then replacing the cassette with $9 c-m y c B$ derived from pSJG4 selecting for sucrose resistance [63].

Plasmid pSJG4 contains $9 c-m y c B$ cloned between NcoI and BamHI sites of pET28a. pSP104 is a mini-Mu donor substrate with att $\mathrm{L}$, att $\mathrm{R}$ and enhancer [57]. pUC19 was used as transposition target (laboratory stock).

$\mathrm{MuA}, \mathrm{MuB}$ and $\mathrm{HU}$ proteins were purified as described previously [64].

\section{Phage purification and DNA extraction}

Induction of $\mathrm{Mu}$ prophage and purification of phage were performed as described previously [34]. The SJG3 and SJG3 $\Delta$ fis strains were harvested at 1.5 hours and the SJG3 $\Delta h n s$ was harvested at 3.5 hours after heat induction. Purified $\mathrm{Mu}$ phage suspended in Mu buffer 
(20 mM Tris- $\mathrm{HCl}, \mathrm{pH} 7.5,0.2 \mathrm{M} \mathrm{NaCl}, 1 \mathrm{mM} \mathrm{CaCl}, 20$ $\mathrm{mM} \mathrm{MgSO}_{4}$ and $1 \%$ gelatin) was digested by pronase $(0.5 \mathrm{mg} / \mathrm{ml})$ at $37^{\circ} \mathrm{C}$ overnight in the presence of 20 mM EDTA (pH 8.0). After digestion, SDS was added to final concentration of $0.5 \%(\mathrm{w} / \mathrm{v})$ and the mixture was incubated at $37^{\circ} \mathrm{C}$ for 1 hour. Mu DNA was then purified by phenol/chloroform extraction and precipitated with an equal volume of isopropanol in the presence of $0.3 \mathrm{M}$ sodium acetate ( $\mathrm{pH} 7.0)$. The DNA pellet was washed twice with $75 \%$ ethanol, vacuum-dried, and dissolved in $10 \mathrm{mM}$ Tris- $\mathrm{HCl}(\mathrm{pH} 7.5)$.

\section{In vitro transposition}

One-step strand transfer reactions contained $30 \mu \mathrm{g} / \mathrm{ml}$ of mini-Mu plasmid DNA, $20 \mu \mathrm{g} / \mathrm{ml}$ target, $10 \mu \mathrm{g} / \mathrm{ml}$ $\mathrm{HU}, 7 \mu \mathrm{g} / \mathrm{ml} \mathrm{MuA}$ and $5 \mu \mathrm{g} / \mathrm{ml} \mathrm{MuB}$ in $20 \mu \mathrm{l}$ of 20 mM HEPES-KOH (pH 7.6), $2 \mathrm{mM}$ ATP, $140 \mathrm{mM} \mathrm{NaCl}$ and $10 \mathrm{mM} \mathrm{MgCl}$. Reactions were incubated at $30^{\circ} \mathrm{C}$ for 30 minutes. Two-step strand transfer reactions were performed as follows. In the first step, cleaved $\mathrm{Mu}$ complexes were assembled at $30^{\circ} \mathrm{C}$ for 20 minutes as described above except without MuB and ATP; in the second step, strand transfer was initiated by adding equal amounts of the reaction mixture to tubes containing $10 \mu \mathrm{g} / \mathrm{ml}$ of various target DNAs, $2 \mathrm{mM}$ ATP and 5 $\mu \mathrm{g} / \mathrm{ml} \mathrm{MuB}$, and the reactions were incubated at $30^{\circ} \mathrm{C}$ for 20 minutes.

\section{FLA of PCR products}

$\mathrm{Mu}$ phage DNA or in vitro strand transfer products were used as templates in PCR reactions with a common $\mathrm{Mu}$ R-end primer labeled at its 5' end with fluorescent agent 6-FAM (Integrated DNA Technologies, Coralville, Iowa, USA) and a second primer annealing to different sites of the $\mathrm{Mu}$ or $E$. coli genome (see Additional file 3). PCR reactions containing $50 \mathrm{ng}$ of input DNA template, 10 pmoles of each primer and $1 \times$ Taq polymerase Master Mix (Qiagen) were placed in a thermal cycler (PTC-200 MJ Research) for 22 cycles. PCR products were purified using a Qiaquick PCR Purification $\mathrm{Kit}^{\circ}$ (Qiagen) and analyzed using a genetic analyzer (3130XL; Applied Biosystems) and interpreted using the analysis software GeneMaker (Version 1.5; SoftGenetics LLC).

ChIP

SJG3, SJG3 $\Delta$ fis and SJG3 $\Delta h n s$ strains were grown to mid-log phase $\left(\mathrm{OD}_{600}\right.$ approximately 0.6$)$ in $\mathrm{LB}$ at $30^{\circ} \mathrm{C}$, and the temperature-sensitive $\mathrm{Mu}$ repressor was inactivated at $42^{\circ} \mathrm{C}$ for 40 minutes. Cells were cross-linked by $1 \%(\mathrm{v} / \mathrm{v})$ formaldehyde $(37 \%(\mathrm{v} / \mathrm{v})$ solution; Fisher Scientific) at room temperature for 30 minutes, and excess formaldehyde was quenched with $125 \mathrm{mM}$ glycine at room temperature for 5 minutes. The cells were collected by centrifugation, washed twice with Tris-buffered saline (pH7.5), and resuspended in lysis buffer containing $50 \mathrm{mM}$ Tris- $\mathrm{HCl}, \mathrm{pH} 7.5,1 \mathrm{mM}$ EDTA, 100 $\mathrm{mM} \mathrm{NaCl}, 4 \mathrm{mg} / \mathrm{ml}$ lysozyme (Roche) and protease inhibitors (1 tablet per $10 \mathrm{ml}$ buffer) (Roche). The suspension was incubated at $37^{\circ} \mathrm{C}$ for 30 minutes, followed by the addition of same volume of $2 \times$ IP buffer (100 $\mathrm{mM}$ Tris- $\mathrm{HCl}$ (pH7.5), $1 \mathrm{mM}$ EDTA, $200 \mathrm{mM} \mathrm{NaCl}$ and $2 \%(\mathrm{v} / \mathrm{v})$ TritonX-100). The lysate was sonicated (Vibra Cell ${ }^{\circ}$, model VC 5051; Sonics) seven times for 20 seconds each in an ice bath to shear the chromatin DNA. The size of DNA resulting from ultrasonication was 300 to $1000 \mathrm{bp}$, with an average size of $500 \mathrm{bp}$. The cell debris generated was removed by centrifugation at $21,000 \mathrm{~g}$ for 15 minutes at $4^{\circ} \mathrm{C}$, and the supernatant was used as 'input' samples for immunoprecipitation. To immunoprecipitate c-myc-MuB-DNA or MuA-DNA, 5 $\mu \mathrm{g}$ of anti-c-myc antibody (9E10; Covance) and anti$\mathrm{MuA}$ serum [28], respectively, were added to $500 \mu \mathrm{l}$ of input samples (MuA anti-serum was purified using Montage Antibody Purification Kit with PROSEP-A media from Millipore, in accordance with their instruction manual.) No-antibody controls ('mock' samples) were included as well. After overnight incubation at $4^{\circ} \mathrm{C}$, $50 \mu \mathrm{l}$ Dynabeads Protein A (Invitrogen) were added to the samples. Following a 5 hour incubation at $4^{\circ} \mathrm{C}$, the beads were washed twice with immunoprecipitation (IP) buffer (50 mM Tris- $\mathrm{HCl}, \mathrm{pH} 7.5,140 \mathrm{mM} \mathrm{NaCl}, 1 \mathrm{mM}$ EDTA and $1 \%(\mathrm{v} / \mathrm{v})$ TritonX-100), once with wash buffer I ( $50 \mathrm{mM}$ Tris-HCl, pH7.5, $500 \mathrm{mM} \mathrm{NaCl}, 1 \mathrm{mM}$ EDTA and 1\% (v/v) TritonX-100), once with wash buffer II $(10 \mathrm{mM}$ Tris- $\mathrm{HCl}, 250 \mathrm{mM} \mathrm{LiCl}, 1 \mathrm{mM}$ EDTA and $1 \%(\mathrm{v} / \mathrm{v})$ TritonX-100) and once with TE buffer (10 $\mathrm{mM}$ Tris-HCl, pH8.0, $1 \mathrm{mM}$ EDTA). After aspirating off the TE buffer, the beads were suspended in $150 \mu \mathrm{l}$ of elution buffer (50 mM Tris-HCl, pH8.0, 10 mM EDTA and $1 \%(\mathrm{v} / \mathrm{v})$ SDS) and incubated for 45 minutes at $65^{\circ}$ C. The supernatant was carefully transferred to a new tube and heated to $65^{\circ} \mathrm{C}$ for at least 6 hours to reverse protein-DNA crosslinking. Afterwards, $150 \mu \mathrm{l}$ of TE buffer were added and the mixture was first treated with $0.5 \mu \mathrm{g} / \mathrm{ml} \mathrm{RNaseA}$ (Sigma) at $37^{\circ} \mathrm{C}$ for 30 minutes and then with $100 \mu \mathrm{g} / \mathrm{ml}$ proteinase $\mathrm{K}$ (Sigma) at $55^{\circ} \mathrm{C}$ for 2 hours. The sample was then purified (Qiaquick PCR Purification Kit ${ }^{\circ}$; Qiagen).

\section{Normal PCR}

An aliquot $(1 \mu \mathrm{l})$ of ChIP or mock sample was added to $5 \mu \mathrm{l}$ of 10x Expand Long Template buffer 1 (Roche), 1.5 $\mu \mathrm{l}$ of dNTP (10 mM each), $1.5 \mu \mathrm{l}$ of each primer (10 $\mu \mathrm{M}), 0.75 \mu \mathrm{l}$ of Expand Long Template Enzyme Mix (Roche), and $38.5 \mu \mathrm{l} \mathrm{H}_{2} \mathrm{O}$. The samples were heated for 2 minutes at $94^{\circ} \mathrm{C}$, after which they underwent 30 cycles of 15 seconds at $94^{\circ} \mathrm{C}, 15$ seconds at $55^{\circ} \mathrm{C}$ and 30 seconds at $68^{\circ} \mathrm{C}$, followed by incubation for 7 minutes at $68^{\circ} \mathrm{C}$ (PTC-200 MJ Research). 


\section{Real-time qPCR}

$\mathrm{Mu}$ insertions within the $\mathrm{Mu}$ genome or the E. coli chromosome were measured by PCR reactions using packaged Mu DNA as template and different primers pairs, all of which had a common primer annealing within the $\mathrm{Mu}$ right end, with the second primer annealing within the region of interest (see Additional file 3). Enrichment of MuB-bound $\mathrm{Mu}$ genome DNA or E. coli chromosome DNA was measured in ChIP samples by PCR reactions using specific primer pairs annealing within these DNAs. The real-time qPCR conditions were: $50 \mathrm{ng}$ of $\mathrm{Mu}$ DNA or $1 \mu \mathrm{l}$ of ChIP or mock-ChIP DNA, $10 \mu \mathrm{l}$ SYBR master mix (Qiagen; includes dNTPs, enzyme and buffer), $0.4 \mu \mathrm{l}$ of each primer $(10 \mu \mathrm{M})$ and $8.2 \mu \mathrm{l}$ of double distilled $\mathrm{H}_{2} \mathrm{O}$. The reactions were held for 10 minutes at $95^{\circ} \mathrm{C}$ followed by 40 cycles of 15 seconds at $95^{\circ} \mathrm{C}$ and 1 minute at $60^{\circ} \mathrm{C}$ (7900HT; Applied Biosystems). Three independent biological replicates were tested, and for each biological replicate three independent technical replicates were performed.

Primer efficiencies were determined as follows: MuR was linked to pUC18f and the various primers were linked to pUC19r; the pUC primers anneal to the pUC19 plasmid and amplify a common $180 \mathrm{bp}$ fragment. The PCR products were purified (Qiaquick PCR purification Kit ${ }^{\oplus}$; Qiagen) and used as templates for qPCR in the following reaction: $12.5 \mu \mathrm{l}$ SYBR mix (Qiagen), $0.75 \mu \mathrm{l}$ of MuR $(10 \mu \mathrm{M})$ paired with various primers $(10 \mu \mathrm{M}), 1 \mu \mathrm{l}$ of template $\left(10^{-5} \mathrm{ng} / \mu \mathrm{l}\right)$ and $10 \mu \mathrm{l}$ of $\mathrm{dd}_{2} \mathrm{O}$. The reactions were held for 10 minutes at $95^{\circ} \mathrm{C}$, followed by 40 cycles of 15 seconds at $95^{\circ} \mathrm{C}$ and 1 minute at $60^{\circ} \mathrm{C}$ (7900HT; Applied Biosystems). The template input amount was controlled by qPCR using the primer pair pUC19f and pUC19r. The primer efficiency of Mu1 was set as 1 , and the efficiencies of the other primer pairs were normalized to that of Mu1.

$\mathrm{Mu}$ copy number was calculated as follows. Genomic DNA was isolated from SJG3 at 0, 20 and 40 minutes after prophage induction (Wizard Genomic DNA Purification Kit, Promega). The purified DNA were diluted to $1 \mathrm{ng} / \mu \mathrm{l}$ and used as template in the following qPCR reactions: $12.5 \mu \mathrm{l}$ SYBR mix (Qiagen), $0.75 \mu$ l of primer pairs within Mu1, $1 \mu \mathrm{l}$ of genomic DNA and $10 \mu \mathrm{l}$ of $\mathrm{ddH}_{2} \mathrm{O}$. The reactions were held for 10 minutes at $95^{\circ} \mathrm{C}$, followed by 40 cycles of 15 seconds at $95^{\circ} \mathrm{C}$ and $1 \mathrm{~min}$ ute at $60^{\circ} \mathrm{C}(7900 \mathrm{HT}$; Applied Biosystems). The template input amount was controlled by qPCR using primer pairs within L25. The Ct differences between Mu1 and L25 represent the copy number of $\mathrm{Mu}$. When the copy number of $\mathrm{Mu}$ at 0 minutes was set as 1 , the copy number at 40 minutes was calculated to be 18 . This number is an average of three technical repeats.
Additional file 1: Figure S1. (a) Lysis profiles of various Mu lysogens. All cultures were grown at $30^{\circ} \mathrm{C}$ to an $\mathrm{OD}_{600} \mathrm{~nm}$ of 0.6 , shifted to $42^{\circ} \mathrm{C}$ for 40 minutes for phage induction, and shifted down to $37^{\circ} \mathrm{C}$ until lysis. 0 indicates time of temperature shift-up. $\Delta$ hns strain did not lyse naturally, so lysis was induced by addition of chloroform. Phage titers from all three strains were similar to those from the parent strain MP1999, yielding around 3 to $5 \times 10^{8} \mathrm{pfu} / \mathrm{ml}$. ChIP samples were prepared at 40 minutes for all SJG3-derived strains. (b) Western blot of MP1999 with anti-MuB antibodies at indicated times after temperature shift-up. Click here for file

[http://www.biomedcentral.com/content/supplementary/1759-8753-1-8S1.JPEG ]

Additional file 2: Figure S2. Moving average AT-content of $\mathrm{Mu}$ genome. The window for average AT-content (\%) calculation is $100 \mathrm{bp}$ and the moving step is $20 \mathrm{bp}$. The value of AT content at a given position represents the average AT content of $100 \mathrm{bp}$ DNA starting from that position. The graph was derived from data in [20].

Click here for file

[http://www.biomedcentral.com/content/supplementary/1759-8753-1-8S2.JPEG ]

Additional file 3: Table S1. Sequence of primers used in this study. Click here for file

[ http://www.biomedcentral.com/content/supplementary/1759-8753-1-8S3.DOCX]

\section{Acknowledgements}

This work was supported by National Institutes of Health grant GM 33247 and in part by the Robert Welch Foundation Grant F-1351. We thank Martin Pato for strain MP1999.

\section{Authors' contributions}

$J G$ designed the experiments, performed the research and analyzed the data. ZL assisted with the research. RMH conceived of the study, participated in its design and coordination and helped to draft the manuscript. All authors read and approved the final manuscript.

\section{Competing interests}

The authors declare that they have no competing interests.

Received: 1 November 2009

Accepted: 1 February 2010 Published: 1 February 2010

\section{References}

1. Craig NL: Target site selection in transposition. Annu Rev Biochem 1997, 66:437-474.

2. Adzuma K, Mizuuchi K: Target immunity of Mu transposition reflects a differential distribution of Mu B protein. Cell 1988, 53:257-266.

3. Adzuma K, Mizuuchi $\mathrm{K}$ : Interaction of proteins located at a distance along DNA: mechanism of target immunity in the Mu DNA strand-transfer reaction. Cell 1989, 57:41-47.

4. Mizuuchi K: Transpositional recombination: mechanistic insights from studies of Mu and other elements. Annu Rev Biochem 1992, 61:1011-1051.

5. Chaconas G, Harshey RM: Transposition of phage Mu DNA. Mobile DNA II Washington DC: ASM PressCraig NL, Craigie R, Gellert M, Lambowitz AM 2002, 384-402.

6. Greene EC, Mizuuchi K: Target immunity during Mu DNA transposition. Transpososome assembly and DNA looping enhance MuA-mediated disassembly of the MuB target complex. Mol Cell 2002, 10:1367-1378.

7. Bainton RJ, Kubo KM, Feng JN, Craig NL: Tn7 transposition: target DNA recognition is mediated by multiple Tn7-encoded proteins in a purified in vitro system. Cell 1993, 72:931-943.

8. Stellwagen AE, Craig NL: Avoiding self: two Tn7-encoded proteins mediate target immunity in Tn7 transposition. Embo J 1997, 16:6823-6834.

9. Mogutov MA, Velikodvorskaia GA, Kobets NS, Piruzian ES: Transposition immunity in bacteriophage Mu. The effect of a mutation at the kil gene on the establishment of immunity. Genetika 1985, 21:927-935. 
10. Reyes O, Beyou A, Mignotte-Vieux C, Richaud F: Mini-Mu transduction: cisinhibition of the insertion of Mud transposons. Plasmid 1987, 18:183-192.

11. Manna D, Higgins NP: Phage Mu transposition immunity reflects supercoil domain structure of the chromosome. Mol Microbiol 1999, 32:595-606.

12. Lee $M S$, Craigie R: A previously unidentified host protein protects retroviral DNA from autointegration. Proc Natl Acad Sci USA 1998, 95:1528-1533.

13. Lin CW, Engelman A: The barrier-to-autointegration factor is a component of functional human immunodeficiency virus type 1 preintegration complexes. J Virol 2003, 77:5030-5036.

14. Zheng R, Ghirlando R, Lee MS, Mizuuchi K, Krause M, Craigie R: Barrier-toautointegration factor (BAF) bridges DNA in a discrete, higher-order nucleoprotein complex. Proc Natl Acad Sci USA 2000, 97:8997-9002.

15. Bradley CM, Ronning DR, Ghirlando R, Craigie R, Dyda F: Structural basis for DNA bridging by barrier-to-autointegration factor. Nat Struct Mol Biol 2005, 12:935-936.

16. Suzuki Y, Craigie R: Regulatory mechanisms by which barrier-toautointegration factor blocks autointegration and stimulates intermolecular integration of Moloney murine leukemia virus preintegration complexes. J Virol 2002, 76:12376-12380.

17. Greene EC, Mizuuchi K: Visualizing the assembly and disassembly mechanisms of the MuB transposition targeting complex. J Biol Chem 2004, 279:16736-16743.

18. Greene EC, Mizuuchi K: Dynamics of a protein polymer: the assembly and disassembly pathways of the MuB transposition target complex. Embo J 2002, 21:1477-1486.

19. Ge J, Harshey RM: Congruence of in vivo and in vitro insertion patterns in hot $E$. coli gene targets of transposable element $\mathrm{Mu}$ : opposing roles of MuB in target capture and integration. J Mol Biol 2008, 380:598-607.

20. Morgan GJ, Hatfull GF, Casjens S, Hendrix RW: Bacteriophage Mu genome sequence: analysis and comparison with Mu-like prophages in Haemophilus, Neisseria and Deinococcus. J Mol Biol 2002, 317:337-359.

21. Greene EC, Mizuuchi K: Direct observation of single MuB polymers: evidence for a DNA-dependent conformational change for generating an active target complex. Mol Cell 2002, 9:1079-1089.

22. Manna D, Breier AM, Higgins NP: Microarray analysis of transposition targets in Escherichia coli : the impact of transcription. Proc Natl Acad Sci USA 2004, 101:9780-9785.

23. Bukhari Al, Taylor AL: Influence of insertions on packaging of host sequences covalently linked to bacteriophage Mu DNA. Proc Natl Acad Sci USA 1975, 72:4399-4403.

24. Wang X, Higgins NP: 'Muprints' of the lac operon demonstrate physiological control over the randomness of in vivo transposition. $\mathrm{Mol}$ Microbiol 1994, 12:665-677.

25. Manna D, Wang X, Higgins NP: Mu and IS1 transpositions exhibit strong orientation bias at the Escherichia coli bgl locus. J Bacteriol 2001 183:3328-3335.

26. Baker TA, Mizuuchi M, Mizuuchi K: MuB protein allosterically activates strand transfer by the transposase of phage Mu. Cell 1991, 65:1003-1013.

27. Surette MG, Chaconas G: Stimulation of the Mu DNA strand cleavage and intramolecular strand transfer reactions by the $\mathrm{Mu} B$ protein is independent of stable binding of the Mu B protein to DNA. J Biol Chem 1991, 266:17306-17313.

28. Nakayama C, Teplow DB, Harshey RM: Structural domains in phage $\mathrm{Mu}$ transposase: identification of the site-specific DNA-binding domain. Proc Natl Acad Sci USA 1987, 84:1809-1813.

29. Dame RT: The role of nucleoid-associated proteins in the organization and compaction of bacterial chromatin. Mol Microbiol 2005, 56:858-870.

30. Falconi M, McGovern V, Gualerzi C, Hillyard D, Higgins NP: Mutations altering chromosomal protein $\mathrm{H}-\mathrm{NS}$ induce mini-Mu transposition. New Biol 1991, 3:615-625.

31. Betermier M, Poquet I, Alazard R, Chandler M: Involvement of Escherichia coli Fis protein in maintenance of bacteriophage Mu lysogeny by the repressor: control of early transcription and inhibition of transposition. J Bacteriol 1993, 175:3798-3811.

32. van Drunen $\mathrm{CM}$, van Zuylen C, Mientjes EJ, Goosen N, Putte van de P: Inhibition of bacteriophage Mu transposition by Mu repressor and Fis. Mol Microbiol 1993, 10:293-298.
33. Ali Azam T, Iwata A, Nishimura A, Ueda S, Ishihama A: Growth phasedependent variation in protein composition of the Escherichia coli nucleoid. J Bacteriol 1999, 181:6361-6370.

34. Au TK, Agrawal P, Harshey RM: Chromosomal integration mechanism of infecting Mu virion DNA. J Bacteriol 2006, 188:1829-1834.

35. Lavoie BD, Chaconas G: Immunoelectron microscopic analysis of the A, B, and $\mathrm{HU}$ protein content of bacteriophage Mu transpososomes. $\mathrm{J}$ Biol Chem 1990, 265:1623-1627.

36. Naigamwalla DZ, Chaconas G: A new set of Mu DNA transposition intermediates: alternate pathways of target capture preceding strand transfer. Embo J 1997, 16:5227-5234.

37. Adzuma K, Mizuuchi K: Steady-state kinetic analysis of ATP hydrolysis by the B protein of bacteriophage Mu. Involvement of protein oligomerization in the ATPase cycle. J Biol Chem 1991, 266:6159-6167.

38. Ussery D, Larsen TS, Wilkes KT, Friis C, Worning P, Krogh A, Brunak S: Genome organisation and chromatin structure in Escherichia coli. Biochimie 2001, 83:201-212.

39. Luijsterburg MS, Noom MC, Wuite GJ, Dame RT: The architectural role of nucleoid-associated proteins in the organization of bacterial chromatin: a molecular perspective. J Struct Biol 2006, 156:262-272

40. Postow L, Hardy CD, Arsuaga J, Cozzarelli NR: Topological domain structure of the Escherichia coli chromosome. Genes Dev 2004, 18:1766-1779.

41. Stein RA, Deng S, Higgins NP: Measuring chromosome dynamics on different time scales using resolvases with varying half-lives. $\mathrm{Mol}$ Microbiol 2005, 56:1049-1061.

42. Hardy CD, Cozzarelli NR: A genetic selection for supercoiling mutants of Escherichia coli reveals proteins implicated in chromosome structure. $\mathrm{Mol}$ Microbiol 2005, 57:1636-1652.

43. Navarre WW, Porwollik S, Wang Y, McClelland M, Rosen H, Libby SJ, Fang FC: Selective silencing of foreign DNA with low GC content by the H-NS protein in Salmonella. Science 2006, 313:236-238.

44. Wardle SJ, Chan A, Haniford DB: H-NS binds with high affinity to the Tn10 transpososome and promotes transpososome stabilization. Nucleic Acids Res 2009, 37:6148-6160.

45. Pato ML: Central location of the Mu strong gyrase binding site is obligatory for optimal rates of replicative transposition. Proc Natl Acad Sci USA 1994, 91:7056-7060.

46. Pato $M L$, Banerjee $M:$ The Mu strong gyrase-binding site promotes efficient synapsis of the prophage termini. Mol Microbiol 1996, 22:283-292.

47. Pato ML, Howe MM, Higgins NP: A DNA gyrase-binding site at the center of the bacteriophage $\mathrm{Mu}$ genome is required for efficient replicative transposition. Proc Natl Acad Sci USA 1990, 87:8716-8720.

48. Pato ML, Karlok M, Wall C, Higgins NP: Characterization of Mu prophage lacking the central strong gyrase binding site: localization of the block in replication. J Bacteriol 1995, 177:5937-5942.

49. Suzuki $Y$, Yang $H$, Craigie R: LAP2alpha and BAF collaborate to organize the Moloney murine leukemia virus preintegration complex. Embo J 2004, 23:4670-4678.

50. Skoko D, Li M, Huang Y, Mizuuchi M, Cai M, Bradley CM, Pease PJ, Xiao B, Marko JF, Craigie R, Mizuuchi K: Barrier-to-autointegration factor (BAF) condenses DNA by looping. Proc Natl Acad Sci USA 2009, 106:16610-16615.

51. Coros CJ, Sekino Y, Baker TA, Chaconas G: Effect of mutations in the C terminal domain of $\mathrm{Mu} \mathrm{B}$ on DNA binding and interactions with $\mathrm{Mu} \mathrm{A}$ transposase. J Biol Chem 2003, 278:31210-31217.

52. Teplow DB, Nakayama C, Leung PC, Harshey RM: Structure-function relationships in the transposition protein $\mathrm{B}$ of bacteriophage $\mathrm{Mu}$. J Biol Chem 1988, 263:10851-10857.

53. Tan X, Mizuuchi M, Mizuuchi K: DNA transposition target immunity and the determinants of the MuB distribution patterns on DNA. Proc Natl Acad Sci USA 2007, 104:13925-13929.

54. Skoko D, Yoo D, Bai H, Schnurr B, Yan J, McLeod SM, Marko JF, Johnson RC: Mechanism of chromosome compaction and looping by the Escherichia coli nucleoid protein Fis. J Mol Biol 2006, 364:777-798.

55. Watson MA, Chaconas G: Three-site synapsis during Mu DNA transposition: A critical intermediate preceding engagement of the active site. Cell 1996, 85:435-445.

56. Kobryn K, Watson MA, Allison RG, Chaconas G: The Mu three-site synapse: a strained assembly platform in which delivery of the L1 transposase binding site triggers catalytic commitment. Mol Cell 2002, 10:659-669. 
57. Pathania S, Jayaram M, Harshey RM: Path of DNA within the Mu transpososome. Transposase interactions bridging two Mu ends and the enhancer trap five DNA supercoils. Cell 2002, 109:425-436.

58. Pathania S, Jayaram M, Harshey RM: A unique right end-enhancer complex precedes synapsis of $\mathrm{Mu}$ ends: the enhancer is sequestered within the transpososome throughout transposition. Embo J 2003, 22:3725-3736

59. Yin Z, Suzuki A, Lou Z, Jayaram M, Harshey RM: Interactions of phage Mu enhancer and termini that specify the assembly of a topologically unique interwrapped transpososome. J Mol Biol 2007, 372:382-396.

60. Harshey RM, Jayaram M: The Mu transpososome through a topological lens. Crit Rev Biochem Mol Biol 2006, 41:387-405.

61. Wu Z, Chaconas G: Flanking host sequences can exert an inhibitory effect on the cleavage step of the in vitro Mu DNA strand transfer reaction. J Biol Chem 1992, 267:9552-9558.

62. Datsenko KA, Wanner BL: One-step inactivation of chromosomal genes in Escherichia coli K-12 using PCR products. Proc Natl Acad Sci USA 2000, 97:6640-6645.

63. Sawitzke JA, Thomason LC, Costantino N, Bubunenko M, Datta S, Court DL: Recombineering: in vivo genetic engineering in $E$. col i, S. enterica, and beyond. Methods Enzymol 2007, 421:171-199.

64. Yang JY, Kim K, Jayaram M, Harshey RM: Domain sharing model for active site assembly within the Mu A tetramer during transposition: the enhancer may specify domain contributions. Embo J 1995, 14:2374-2384.

doi:10.1186/1759-8753-1-8

Cite this article as: Ge et al: Immunity of replicating Mu to selfintegration: a novel mechanism employing MuB protein. Mobile DNA 2010 1:8.

\section{Submit your next manuscript to BioMed Central and take full advantage of:}

- Convenient online submission

- Thorough peer review

- No space constraints or color figure charges

- Immediate publication on acceptance

- Inclusion in PubMed, CAS, Scopus and Google Scholar

- Research which is freely available for redistribution

Submit your manuscript at www.biomedcentral.com/submit 